\title{
KONFLIK DAN MEDIA (MENUJU PEACE-ORIENTED JOURNALISM)
}

\author{
Eka Hendry Ar
}

\begin{abstract}
Abstrak
Media adalah tetap merupakan sebuah instrument positif dalam artian kegunaannya akan sangat tergantung kepada man behind the gun dari media tersebut. Apalagi media, ia tidak dapat memisahkan dirinya dari dinamika politik dan ekonomi yang sedang berkembang. Media harus memainkan peran pendidikan, dengan memberikan suara kepada semua pihak, sehingga opini masing-masing pihak yang berkonflik tersampaikan kepada yang lain, sehingga stereotype yang ada dapat dicairkan, dan ada evaluasi dan klarifikasi terhadap persepsi yang telah terbangun dari awal. Jadi ada proses reframing tentang isu dan perdebatan, sehingga ini nantinya dapat membantu pihak-pihak yang berkonflik untuk mengidentikasi kesamaan problem yang menyebabkan konflik.
\end{abstract}

Kata Kunci: perselisihan, informasi, hubungan antar etnik

\section{A. Pendahuluan}

Manakala kita bicara tentang
konflik social (yang disertai
kekerasan), biasanya bersamaan
dengan hal tersebut kita melihat peran
yang dimainkan oleh Media, terutama
media masa cetak dan audio visual.

Karena biasanya, berita tentang konflik selalu menjadi berita yang seksi untuk dikonsumsi publik. Adagium bad news is good news masih menjadi fenomena yang jamak dijumpai dalam media massa kita. Oleh karenanya, tidak jarang selain sebagai wahana menyampaikan informasi, media juga terkadang menjadi media "provokasi" terhadap pembacanya, jika pemberitaan tidak sensitif terhadap isi berita yang disampaikan dan implikasi (yang mungkin timbul) dari berita tersebut bagi publik. Setidaknya itu yang dilaporkan oleh Eriyanto (2005) dalam laporan penelitiannya tentang pemberitaan media massa terhadap konflik Ambon. Media tidak jarang memperkeruh suana, bahkan yang menarik dari laporan tersebut, terjadi "konflik" antar media yang berbasis sentimen agama. 
Demikian pula ketika relasi terbangun dengan fenomena teroris (isu-isu dan aktor teroris) sebagaimana yang sedang in (up to date) sekarang, maka ada hubungan resiprokal yang sangat kuat antara keduanya. Brigitte Nacos (dalam Benjamin Cole, 2006:12) bahkan mengistilahkan relasi keduanya dengan marriage of convenience, karena kedua belah pihak saling membutuhkan dan saling mengambil keuntungan dari kedekatan tersebut. Teroris membutuhkan media untuk mengkomunikasikan pesanpesan mereka, sementara media berkepentingan dengan pemberitaan tentang teroris karena dapat menjadi pengatrol rating pemberitaan.

Jadi ada dua peran media, di satu sisi ia sebagai wahana penyampai berita, namun di sisi lain ia juga bisa menjadi sebagai "pembuat cerita", seperti yang dikemukakan dalam teori agenda setting. Berdasarkan realitas tersebut, penulis merasa perlu mengangkat persoalan ini menjadi satu tema diskusi, yaitu bagaimana hubungan antara realitas konflik dengan peran yang dimainkan oleh media.

\section{B. Hakekat dan Fungsi Media}

Media pada hakekatnya tidak bisa direduksi hanya sebatas media massa cetak atau audio visual semata, akan tetapi media itu mencakup penerbitan buku, jurnal, laporan penelitian sampai kepada alat-alat tekhnologi komunikasi mutakhir seperti hand phone dan jaringan komunikasi social melalui media seperti FB, BB dlsb. (Lee Marsden and Heather Savigny, 2009:146). Jadi, media dapat diartikan sebagai sarana atau wahana yang digunakan oleh manusia untuk mendokumentasikan dan menyampaikan informasi atau datadata kepada pembaca. Perbedaannya terletak pada tata cara penulisan pesannya dan bobot kadar ilmiah pada masing-masing media tersebut. Kalau berita di sebuah media massa seperti Koran dan telivisi lebih bersifat informatif dan current news, gaya bahasanya simpel, deskriftif agar mudah dimengerti oleh pembaca. Bobot ilmiah tidak terlalu ditekankan, karena kebenaran informasi yang disampaikan melalui media cetak bersifat terbuka dan dapat dikonfirmasi melalui hak jawab dari para sumber berita. Berbeda halnya dengan sebuah hasil penelitian yang kemudian dibukukan dalam sebuah buku ilmiah, selain keakuratan contentnya, juga ditekankan tentang ketepatan metode dan persfektif yang digunakan dalam tulisan tersebut. Karena target dari 
sebuah buku ilmiah itu untuk jangka waktu yang panjang, maka dihindari pola penulisan yang bersifat berita. Untuk membantah kebenaran sebuah penelitian ilmiah yang dipublikasi diperlukan sebuah penelitian ilmiah lain, tidak memadai hanya dengan kritikan "pepesan kosong" semata. Dalam konteks tulisan ini, penulis lebih banyak menyoroti media dalam bentuk media massa baik cetak maupun audio visual, agar kajian kita tidak terlalu meluas ke semua jenis media.

Dalam konteks umum, media memiliki beberapa fungsi, seperti sebagai jendela informasi bagi pembaca, sarana edukasi dan pencerahan bagi masyarakat, wahana kritik dan kontrol sosial (watchdog role), sampai wahana entertainment yang memberikah hiburan bagi masyarakat. Namun demikian, keberadaan media biasanya tidak kedap dari dinamika politik dan ekonomi di suatu wilayah tertentu. Karena media senantiasa berada dalam pusaran kegiatan politik dan ekonomi. Sehingga tidak jarang media terhegemoni oleh kepentingan politik (dan kekuasaan) dan dunia industri (kepentingan ekonomi).

Seperti yang terjadi pada masa orde baru, media (terutama media cetak dan audio visual) dijadikan "alat kekuasaan" oleh pemerintah Orde Baru. Selain tidak adanya kebebasan pers, media massa juga seringkali dihegemoni oleh kekuasaan yang ada, sebagai sarana untuk menjembatani kepentingan politik pemerintah. Pers yang tidak sejalan dengan kepentingan pemerintah akan dibredel secara paksa. Terlepas dari kepentingan dan hegemoni oleh pemerintah, yang jelas ada kesan bahwa, pemerintah memandang penting peran yang dimainkan oleh Pers.

Kesadaran akan pentingnya "menghegemoni" media juga berlangsung hingga kini. Terlebih lagi di era tekhnologi informasi yang canggih seperti sekarang, orang berlomba-lomba untuk "menguasai" media massa. Tidak terkecuali para elit politik berpikiran perlu menguasai media, untuk memuluskan kepentingan politik mereka. Dalam politik, media juga berperan dalam mempublikasi isu, visi dan misi calon atau partai politik, disamping memberikan kritik terhadap para politikus. (K. Marijan, 2010) Ini yang disebut oleh Douglas Kellner (dalam Jonathan Woodier, 2006:42) dengan model hegemony yaitu dimana para elit politik di Indonesia berupaya memaksa media bekerja sesuai dengan kepentingan yang mereka 
persepsikan dan upaya mereka untuk merestore peran gate keeping media terhadap arus berita dan informasi dalam batas-batas kepentingan elit politik. Hal ini menurut Kellner menunjukkan bahwa, bagi kalangan elit politik (nasional dan lokal) media memiliki peran yang sentral bagi kehidupan masyarakat, oleh karenanya menjadi penting untuk menguasai media.

Terlebih lagi di era demokrasi sekarang ini, media merupakan salah satu pilar dari tegaknya demokrasi. Dalam alam demokrasi media diharapkan dapat menjadi wahana check and balance antara pemerintah dengan rakyatnya, sehingga demokrasi dapat berjalan pada koridor yang tepat. Pengalaman politik Indonesia memperlihatkan bagaimana dinamika perkembangan media dan kebebasan press. Setelah runtuhnya rezim Orde Baru, dunia pers seakanakan memasuki babak baru dari "kemerdekaan pers". Seperti dicatat Jonathan Woodier (dalam Benjamin Cole, 2006:43) bahwa, pada 13 September 1999, hari-hari terakhir 17 bulan kepemimpinan BJ. Habibie, DPR-RI menganulir beberapa pasal dari Undang-Undang Pers tahun 1966 dan 1982 (yang dibuat pada masa pemerintahan Presiden Suharto).
Fenomena politik ini dianggap sebagai sesuatu yang luar biasa bagi dunia pers di Indonesia. Bahkan langkah yang luar biasa ditempuh oleh Presiden Gus Dur dengan menghapus Menteri Penerangan, yang selama era ORBA berfungsi sebagai "tukang sensor dan kontrol" media komunikasi.

Dampak dari kebijakan ini adalah terjadinya apa yang disebut oleh Woodier (dalam Benjamin Cole, 2006: 43) dengan $A$ media explosion (ledakan media) yang ditandai dengan bermunculannya media-media massa baru, baik cetak, televisi dan radio. Berdasarkan South East Asian Press Alliance $\left(\right.$ SEAPA) ${ }^{1}$ pada akhir 1999, ada sekitar 299 koran, 886 tabloid, 491 majalah, 11 buletin, 12 Stasiun TV dan 1,110 stasiun radio di Indonesia. Euphoria yang luar biasa terjadi dalam dunia media di Indonesia ini, tentu saja mengembirakan di satu sisi, namun di sisi lain tidak jarang menimbulkan masalah. Terutama berkenaan dengan batasan atau ukuran dari ekspresi kebebasan press, terlebih lagi jika dikaitkan dengan fenomena konflik dan kekerasan yang jamak terjadi

1 . Tahun 2008 ada kenaikan jumlah media, 380 majalah, 692 tabloid, 323 surat Kabar dan 3 buletn yang mendapat izin dari pemerintah. ( Kacong Marijan, 2010) 
setelah peralihan kekuasaan dari era ORBA ke era Reformasi.

Satu hal penting yang harus dicatat dalam hingar binggar kebebasan pers tersebut adalah bahwa, media adalah tetap merupakan sebuah instrument positif dalam artian kegunaannya akan sangat tergantung kepada man behind the gun dari media tersebut. Apalagi media, ia tidak dapat memisahkan dirinya dari dinamika politik dan ekonomi yang sedang berkembang. Seperti digambarkan oleh Lee Marsden and Heather Savigny (2009: 158) bahwa, media, agama dan konflik merupakan bagian yang tidak terpisahkan dalam konteks politik. Ada hubungan yang dialektik dan cair (serta saling mempengaruhi) antara ketiganya dalam konteks politik. Dengan kata lain bahwa, untuk memahami peran media dalam masyarakat, kita harus melihat trend politik (dan ekonomi) yang berkembang dalam masyarakat, termasuk pada saat kita memahami peran media ini dalam konteks konflik kekerasan. Lee Marsden dan Heather juga mengingatkan bahwa, media tidak kedap dari hegemoni market kapitalisme, yang hanya akan memperalat media sebagai alat pengeruk keuntungan materi semata. Oleh karenanya, penting bagi kita untuk melihat dinamika tersebut manakala kita bicara tentang peran media dalam masyarakat, termasuk dalam masalah konflik kekerasan.

\section{Peran media dalam konflik}

Daya Kishan Thussu dan Des Freedman (2003:4) dalam pendahuluan bukunya War and The Media menyatakan bahwa, ada 3 naratif kunci tentang peran media arus utama dalam mengkomunikasikan tentang konflik yaitu sebagai pengamat yang kritis (critical observer), sebagai penyampai berita (publicist) dan sebagai "surface (permukaan) atau "wajah" berita dari medan perang (battleground). Idealnya media yang profesional harus dapat bersikap impartial (tidak memihak) dan menjadi monitor yang independent dalam memberitakan persoalan konflik. Dalam konteks tulisannya, Daya dan Freedman lebih bicara tentang konflik yang melibatkan militer, sehingga ia perlu menekankan tentang dua hal tersebut, terutama ketika berhadapan dengan militer.

Dalam konteks konflik sosial seperti yang terjadi di Kalimantan Barat, idealnya media juga harus bersikap profesional dan impartial (tidak diskriminatif) dalam memuat berita. Demikian pula laporan-laporan 
penelitian yang dipublis juga harus bersikap profesional dan impartial. Media dapat berperan sebagai jendela informasi, menjadi pengamat sosial yang kritis (critical observer) atau bahkan menjadi "penjaga" (watchdog role) agar tidak ada kebijakan pemerintah yang keliru atau masalah yang terlewatkan tanpa ada kebijakan yang dilakukan. Namun fungsi-fungsi konvensional ini sebenarnya belum cukup jika media mau terlibat dalam pemberitaan tentang konflik, karena ada hal yang lebih penting dari itu semua yaitu apa yang menjadi interest dari media. Apakah media memiliki peran ideologis tertentu terkait dengan persoalan konflik ini. Pertanyaan ini penting mengingat tidak sedikit media yang hanya sekedar mementingkan oplah atau rating pemberitaan. Karena berita tentang konflik termasuk kategori berita utama yang menarik perhatian banyak kalangan, maka "komersialisasi" berita ini sulit dihindari.

Untuk mengatasi persoalan ini, maka peran ideologis media harus diperhatikan yaitu bagaimana media menempatkan diri menjadi bagian dari proses resolusi konflik atau peace building dalam situasi konflik. Oleh karenanya, media harus tetap profesional dan impartial, namun bukan berarti media tidak punya citacita ideologis yang lebih besar untuk kepentingan umum. Mengutip pendapat Daniel Hallin (dalam Daya Kishan Thussu dan Des Freedman, 2003:6) bahwa, jurnalis dalam memberitakan tentang perang atau konflik, ia tidak harus memerankan diri sebagai pengamat yang tidak punya kepentingan (disinterested observer), tetapi jadilah seorang patriot dari apa yang disebut dengan peace offensive. Dengan kata lain, Hallin ingin mengatakan bahwa, meskipun kita harus tetap menjunjung tinggi profesionalisme dan impartialitas, namun kita tidak bisa membiarkan berita tentang perang atau konflik berjalan secara "telanjang", tanpa ada upaya kita untuk mengiring kepada kondisi yang lebih baik (peace offensive). Atau dalam bahasa Robert Manoff (dalam Graham Spencer, 2005:170) bahwa, seharusnya media tidak memerankan dirinya sebagai independent observers dari konflik, akan tetapi media seharusnya secara aktif mencari pencegahan agar konflik tidak terjadi. Lebih lanjut dikatakan Manoff bahwa, media harus menjadi pressure terhadap pihak-pihak untuk menyelesaikan konflik, atau mendorong intervensi pihak lain (dalam konteks kita, mungkin 
pemerintah pusat maupun perhatian ineternasional).

Jika media mau melakukan peran ideologis ini tentu saja akan sangat membantu dari proses resolusi konflik, karena media memiliki banyak kelebihan. Selain ia sebagai sesuatu yang sentral dalam masyarakat, ia juga dapat menjadi wahana untuk membentuk wacana dan pandangan masyarakat. Seperti teori agenda setting $^{2}$, dimana media dapat memerankan sebagai pembentuk opini bagi masyarakat. Karena biasanya apa yang dianggap sebagai sesuatu yang penting oleh media, itu juga dipandang penting oleh pembacara (khalayak). Sebagai contoh, ketika media terus menerus memberitakan tentang satu kasus konflik dengan segala dampak yang ditimbulkan oleh konflik tersebut, maka publik akan menganggap bahwa, masalah tersebut merupakan masalah yang serius. Seperti yang terjadi sekarang ini, kasus pembantaian di Mesuji Lampung, karena terus menerus diberitakan, gambarnya terus dimuat di televisi dan koran, publik merasa penting mengetahui perkembangan

\footnotetext{
2 . Teori agenda setting : process by which the relative attention given to items or issues in news coverage influences the rank order of public awareness of issues and attribution of significance. As an extention, effects on public policy may occur". (Denis McQuail, 2000)
}

yang terjadi di Mesuji. Publik mulai mengembangkan wacana tentang konflik tersebut, mulai dari sikap prihatin, kritik terhadap pemerintah dan aparat hingga mencari kambing hitam dari konflik tersebut. Jadi, media dapat memainkan perang discourse keeper bagi masyarakat, dan dapat menarik masyarakat untuk berpikir bahwa, inisiatif untuk perdamaian merupakan hal yang sangat penting dan mendesak untuk dilakukan.

\section{Membangun Jurnalisme Damai (peace-oriented journalism)}

Istilah ini penulis ambil dari salah satu sub judul dari buku The Media and Peace: From Vietnam to the War on Terror karya Graham Spencer. Istilah ini dikembangkan dalam rangka agar media dapat berperan menjadikan publik mengerti tentang penyebab-penyebab konflik, memahami tentang berbagai pendekatan untuk menafsirkan konflik dan artikulasi dialog dalam rangka mengajukan solusi yang konstruktif bagi penyelesaian konflik. (Graham Spencer, 2005:165) Dengan kata lain, pers atau media pada umumnya, harus berperan mendorong inisiatif perdamaian, dengan cara memberikan informasi yang benar dan akurat tentang apa yang sesungguhnya 
sedang terjadi dan sekaligus sebagai pengingat bahwa ada solusi perdamaian yang dapat kita tempuh. (Graham Spencer, 2005:165) Lebih lanjut menurut Graham, media juga harus berupaya melawan opini yang dikembangkan oleh pihak-pihak yang mengembangkan opini yang cenderung melawan kepentingan perdamaian. Pers atau media juga hendaknya tidak malah menyebarkan "rasa ketakutan", rasa tidak toleran dan sesuatu yang dapat menimbulkan kebencian terhadap pihak-pihak yang berkonflik. Oleh karenaya, diperlukan publikasi yang benar-benar penuh perhitungan untuk jangka pendek dan jangka panjang. Memang terkadang ada pilihan yang dilematis, antara mengungkapkan fakta apa adanya, dan keharus kita menjaga sebuah ideologi perdamaian. Disinilah diperlukan kearifan dari masingmasing kita untuk dapat menyajikan berita yang lebih baik.

Galtung dan Vincent (dalam Graham Spencer, 2005:167) memberikan 10 koridor (atau istilah mereka proposal) tentang bagaimana mengembangkan media yang berorientasi damai (peace-oriented media) sebagai berikut:

1. Kapanpun konflik itu ada, salah satu tugas dasar bahkan kewajiban dari media adalah memberikan suara bagi kedua belah pihak atau semua pihak yang ada dalam konflik.

2. Media harus mencoba untuk membuat beberapa teori yang eksplisit, kerangka kerja intelektual (the intelectual frame of reference) dan wacana atau paradigma dimana konflik dipahamai. Dengan kata lain, media harus membuat kerangka teori atau paradigma yang jelas untuk memahami konflik yang sedang terjadi.

3. Kepemilikan media tidak perlu dipersoalkan dan dua tuntutan sebelumnya juga semestinya disampaikan kepada media yang dimiliki oleh pihak yang mempunyai kepentingan baik perusahaan maupun pemerintah .

4. Media seharusnya tidak menjadi korban dari 4 kecenderungan utama dalam pemberitaan: terlalu menyoroti negara-negara elit, terlalu menyoroti kalangan elit, terlalu menyoroti orang-orang tertentu secara pribadi dan terlalu menyoroti peristiwa-peristiwa negatif.

5. Media seharusnya memberikan perhatian untuk enhancing the retention element dari laporan 
berita, dan tidak mengurui (talk down) kepada audien dan pembacanya.

6. Media seharus berusaha keras untuk memahami konflik bersenjata dan berupaya menawarkan ruang yang dapat meminimalisir kecenderungan untuk mencari tempat untuk meminta bantuan persenjataan ketika konflik tidak dapat diselesaikan.

7. Media seharusnya lebih memperhatikan kepada dinamika internal perlombaan/persainganan persenjataan dan konflik bersenjatan.

8. Ketika gencatan senjata di capai, negosiasi dilakukan antara pihak yang berkonflik, sampai kepada perlucutan senjata secara umum, negosiasi-negosiasi perlucutan senjata dan konferensi pada khususnya, dan pertemuan tingkat tinggi bahkan lebih khusus lagi, maka media harus lebih memperhatikan kelemahankelemahan mereka sendiri ketika melaporkan fenomena tersebut. Dengan kata lain, media harus menyadari bahwa mereka memiliki keterbatasan untuk mencover semua informasi secara komprehensif.
9. Media seharusnya melihat formasi konflik (termasuk perdamaian dan perang) antara dunia Utara dan Selatan, jangan hanya melihat problem perdamaian dan perang diantara negara-negara industrialisasi saja.

10. Media seharusnya mencari potret yang lebih jelas tentang manfaat perdamaian.

Kesepuluh prinsip atau proposal tersebut secara kontekstual dapat kita kembangkan sebagai koridor dalam membangun peace journalism di Kalimantan Barat. Spencer mengingatkan kita, terlepas dari kesepuluh koridor tersebut (dan mana yang cocok dan yang tidak dengan kondisi kita), ada hal yang lebih penting adalah bagaimana media dapat mengembangkan kesadaran dan hati nurani publik melalui beragam opini untuk memfasilitasi tercapainya perdamaian. Lebih lanjut menurut Galtung dan Vincent bahwa, media harus menjadi pihak ketiga yang berupaya membant resolusi konflik secara kontruktif.

Oleh karenanya, media harus memainkan peran pendidikan, dengan memberikan suara kepada semua pihak, sehingga opini masing-masing pihak yang berkonflik tersampaikan 
kepada yang lain, sehingga stereotype yang ada dapat dicairkan, dan ada evaluasi dan klarifikasi terhadap persepsi yang telah terbangun dari awal. Jadi ada proses reframing tentang isu dan perdebatan, sehingga ini nantinya dapat membantu pihakpihak yang berkonflik untuk mengidentikasi kesamaan problem yang menyebabkan konflik. Dengan kata lain, media dapat berperan sebagai sinyal tentang bahaya dari eskalasi konflik dan sekaligus sebagai sinyal bagi peluang-peluang penyelesaian yang dapat diterima oleh kedua belah pihak. Kemudian, Media juga dapat berperan sebagai early warning system yang mengidentifikasi the underground tremors of impending conflict, kemudian dapat memberikan respon lebih awal terhadap potensi tersebut. (Graham Spencer, 2005: 169)

Sebagai rekomendasi dari tulisan ini, penulis sampai kepada kesimpulan bahwa, perlu dilakukan upaya-upaya untuk mendorong fungsi media menjadi media perdamaian atau peace journalism. Dimana kita secara aktif mendorong terwujudkan proses peace building dalam masyarakat kita, dengan memperhatikan beberapa koridor yang dikemukakan oleh Galtung, Vincent maupun Robert
Manoff di atas. Jangan sampai, media massa malah menjadi "juru bicara konflik", yang sibuk mewartakan tentang kekerasan dan perang. Semestinya media massa mengambil peran sebagai "juru bicara perdamaian", yang berupaya mencerahkan pihak-pihak yang berkonflik, dengan beragam harapan dan alternatif inisiatif perdamaian, serta menjadi watchdog terhadap kebijakan pemerintah yang dapat menyebabkan konflik. Kemudian, media hendaknya juga menjadi counter-opinion terhadap opini yang cenderung menyebarkan kebencian, prasangka, rasa ketakutan dan permusuhan. Dengan demikian, media benar-benar dapat menjadi pilar resolusi konflik, bersanding dengan pilar-pilar resolusi konflik lainnya.

\section{E. Daftar Pustaka}

Benjamin Cole (ed). 2006. Conflict, Terrorism and The Media In Asia. Routledge Taylor and Francis Group. London and New York.

Daya Kishan Thussu and Des Freedman (ed). 2003. War and The Media. Sage Publication, London and New Delhi.

Denis McQuail. 2000. Mass Communication Theory. Thousand Oakes: Sage. 
Eriyanto. 2005. Koran, Bisnis, dan Perang. Dikutip dalam A. Harsono dan B. Setiono (ed). Jurnalisme Sastrwai. Yayasan Pantau. Jakarta.

Graham Spencer. 2005. The Media and Peace: From Vietnam to The War on Terror. Palgrave Macmillan. New York.

Kacung Marijan. 2010. Sistem Politik Indonesia; Konsolidasi Demokrasi Pasca-Orde Baru. Kencana. Jakarta.

Lee Marsden and Heather Savigny (ed). 2009. Media, Religion and Conflict. Asghate Publishing Limited. England and USA. 